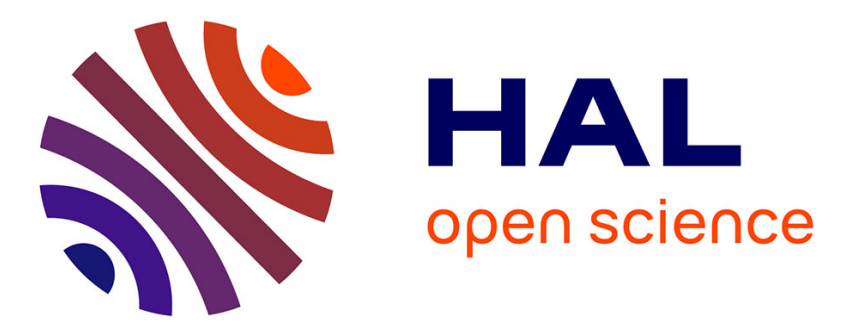

\title{
(Re)discovering the social responsibility of business in Germany
}

Ariane Berthoin Antal, Maria Oppen, André Sobczak

\section{To cite this version:}

Ariane Berthoin Antal, Maria Oppen, André Sobczak. (Re)discovering the social responsibility of business in Germany. Journal of Business Ethics, 2009, 89 (supp.3), pp.285-301. 10.1007/s10551-0100390-8 . hal-00794639

\section{HAL Id: hal-00794639 \\ https://hal-audencia.archives-ouvertes.fr/hal-00794639}

Submitted on 2 Sep 2013

HAL is a multi-disciplinary open access archive for the deposit and dissemination of scientific research documents, whether they are published or not. The documents may come from teaching and research institutions in France or abroad, or from public or private research centers.
L'archive ouverte pluridisciplinaire HAL, est destinée au dépôt et à la diffusion de documents scientifiques de niveau recherche, publiés ou non, émanant des établissements d'enseignement et de recherche français ou étrangers, des laboratoires publics ou privés. 


\title{
(Re)discovering the Social Responsibility of Business in Germany
}

\author{
Ariane Berthoin Antal \\ Professor of organizational change and cross-cultural management at the Technical University of \\ Berlin, Professor in the international affiliate faculty of Audencia Nantes School of Management
}

\section{Maria Oppen}

Researcher at the Wissenschaftszentrum Berlin für Sozialforschung

\section{André Sobczak}

Associate professor at Audencia School of Management in Nantes, Head of the Institute for Global Responsibility of Audencia Nantes School of Management

\begin{abstract}
The concept of corporate social responsibility (CSR) is a relatively recent addition to the agenda in Germany, although the country has a long history of companies practicing social responsibilities. The expectations of society had remained stable for many years, encapsulated in laws, societal norms, and industrial relations agreements. But the past decade has seen significant changes in Germany, challenging established ways of treating the role of business in society. This contribution reviews and illustrates the development of diverse forms of social responsibility in German corporations and analyzes how actors in business and society can build on traditional strengths to find new institutional arrangements for sharing tasks and responsibilities in the interests of achieving a better balance between societal, economic, and environmental needs.
\end{abstract}

KEY WORDS: corporate social responsibility, business ethics, Germany, global responsibility, intentional experimentation

\section{Introduction}

For many years Germany was considered a role model in assuring good product quality, employment and working conditions, workers' involvement, public services, and environmental protection. These high standards have served Germany and its economic development well for many years, both domestically and on international markets. In essence, "doing well by doing good" was required of German companies by the multiple institutional mechanisms that embedded business in society. Although the term "corporate social responsibility" (CSR) was not part of the German vocabulary, socially responsible practices were expected and these expectations were generally met.

However, during the past decade, a number of significant problems have emerged, calling into question the appropriateness of corporate practices in Germany, so the topic of the responsibility of business has been put on the agenda. The revelation of several major scandals in leading German corporations (e.g., Deutsche Bank, Volkswagen, and Siemens) has shown that there are problems in the realm of business ethics. Recent internationally comparative research on business ethics revealed that German respondents have become particularly pessimistic about the likelihood of corporations 
acting responsibly in future (Tsalikis and Seaton, 2007). More generally, at least three interrelated processes are undermining the country's ability to maintain and develop high standards. 'The massive loss of jobs that resulted from the collapse of the East German economy in the wake of reunification has not yet been overcome. The significant gap between the living conditions in the Eastern and the Western parts of the country requires the ongoing transfer of funds, draining public budgets and leading to cutbacks in public social services. (2) Global competition, too, is eroding standards and contributing to problems in Germany such as high unemployment, declining social security, and urban decay (Häußermann et al., 2004; Keller and Seifert, 2006). (3) At the same time, the center of gravity for determining standards is shifting away from the nation state towards negotiations at the international and the supranational level and, increasingly, with various representatives of civil society.

In addition to the shifts in the global context that Germany must grapple with to prepare its future, the nature of problems is changing too. A growing number of society's challenges, in Germany and elsewhere, are perceived as "wicked issues" (Clarke and Stewart, 1997). Problems associated with illicit work, migration, or epidemic diseases appear intractable because they often have multiple root causes and they cross sectoral or national boundaries. Dealing with them effectively therefore requires drawing together a range of resources and competences from multiple actors. There is growing recognition that the distribution of roles and responsibilities between actors in society must change because the state alone can no longer be relied onto meet the needs of society. In many cases the public sector has neither sufficient funds nor expertise to deal with the complex issues threatening the economic, social, and environmental health of the country. As a result, the business community is increasingly being expected to step into help, blurring the lines that have traditionally been drawn between the public and the private sector.

It is perhaps not surprising in this context that the term "corporate social responsibility" has only relatively recently started receiving increasing attention in Germany (Berthoin Antal et al., 2002; Loew et al., 2004), particularly after the European Union launched initiatives in this area in 2001. The social responsibility of business was not subject to explicit discussion for many years because the relations between business and its employees and business and society were covered by legal requirements, societal norms, and tripartite conflict resolution procedures. In addition, internationally comparative research on the related aspect of business ethics suggests that a lack of explicit discussion may also have been due to a culturally engrained reluctance to address normative questions publicly, hampered by a preference for relying on a "traditional but fading business ethos" (Palazzo, 2002, p. 196; Ulrich et al., 1996).

This article explores a key challenge Germany faces in shaping its future, namely how to take on board fresh impulses for negotiating the ways and means of generating a healthy balance between social, economic, and environmental needs. The learning agenda to achieve this end encompasses building on Germany's own past experience with the distribution of social responsibility and with the processes of conflict resolution inherent in the German corporatist tradition (Berthoin Antal et al., 2007). It offers opportunities to renew these traditions and to adapt them to the global context. Furthermore, it entails capitalizing on its second mover advantage by learning from the successes and mistakes made in other countries in recent years. 
This article is organized in two sections. The first analyzes the reception of the CSR concept in Germany. It starts with providing some background about the German context, which is characterized by a high level of social regulation requiring companies to take on responsibilities beyond their direct economic ones. This tradition of social responsibility could be expected to have favored the reception of the CSR concept in Germany (Campbell, 2006). However, in fact it made it more difficult because its added value was less evident than in national contexts where social regulation was weaker. The section then describes the fragmented way the idea of CSR has nevertheless entered German companies over the last 30 years. It shows that although there is an increasing number of interesting initiatives, they usually focus on particular issues without being integrated in a general approach and without changing the way management makes decisions. The second section outlines perspectives for the future by exploring potential routes the key actors in Germany could take to move beyond their current approach of muddling through. It suggests that the term "CSR" may be a limiting factor in achieving change and therefore introduces the term of global responsibility that establishes a more inclusive framework for the learning agenda. It proposes that the German actors engage in intentional experimentation to develop a more interactive and integrated approach to balancing their diverse interests and responsibilities. Two examples illustrate initiatives Germany can build on. To conclude, some of the conditions are identified that are required for effective learning processes in German organizations seeking to put global responsibility into practice.

\section{The fragmented development of CSR in Germany}

The "revival" (Vogel, 2005, p. 1) of CSR as a worldwide phenomenon is part of a wider public debate on the change in the relationships between business, government, and civil society. It highlights the interdependencies between these spheres and sees the analytical distinction that has dominated much of Western thought "as an artificial divorce of what otherwise inseparably belongs together" (Spilotis, 2006, p. 55). It seems to be symptomatic of a search for new organizational forms and institutional frames related to changing roles and responsibilities (see Argandon a, 2004 for a discussion of the relationship between institutions and ethics). The implications for business are twofold. On the one hand, CSR entails expanding the scope of action of business in society because companies are being expected to participate in solving complex problems that government can no longer manage alone. On the other hand, CSR is also a means of reining business in and bringing its activities under public scrutiny. Government agencies and representatives of civil society are demanding that companies expand their reporting beyond financial information to cover the social and environmental impacts of business activities. Furthermore, business is under pressure not only to inform but also to involve stakeholders in strategic decisions that affect society, even leading to the revision of corporate governance mechanisms. The emergence of the internet as a medium for rapid communication around the world has enabled stakeholders to share the data they have about the negative impacts of a multinational corporation's performance, so that business cannot control the distribution and interpretation of information concerning its activities.

The dual nature of CSR as a means of restricting as well as expanding the role of business in society has elicited two kinds of responses from companies: defensive engagement in CSR to keep critics at bay and to prevent external regulation; and proactive involvement to shape the agenda and benefit from new market opportunities and improved management processes. Most major companies have recognized that they cannot afford not to show some level of interest in CSR (Smith, 2003). As the 
Economist recently pointed out, "It would be a challenge to find a recent annual report of any big international company that justifies the firm's existence merely in terms of profit, rather than 'service to the community'"' (Crook, 2005, p. 3). Some companies may start defensively, then discover that pursuing CSR enables them to learn new ways of responding to consumer interests, leading to improved, processes, products, or services (Siebenhuener et al., 2006). Consultants and academics in business schools have been stimulating such learning in companies by developing management tools for assessing risks and monitoring CSR performance (e.g., Triple Bottom Line). Business organizations and NGOs, sometimes working together in international groups, have also developed standards and reporting tools (e.g., Global Reporting Initiative), and they have shared experiences with implementing CSR activities via learning platforms (e.g., the United Nations Global Compact).

These global trends in the development of CSR and the numerous debates in business, policymaking, and civil society have not passed Germany by (Re)discovering the Social Responsibility of Business in Germany 287 unnoticed. They increasingly influence the expectations placed on the roles and responsibilities of business in society. In order to explore this development and future options in Germany, we start with a presentation of the way social responsibility was implicitly1 (Matten and Moon, 2008) conceived and practiced before the CSR concept entered Germany. Then we explore the outlook for Germany, drawing on examples that the various actors could build on in future.

\section{The social responsibility of business in Germany "before CSR"}

The relations between business and society are defined in different ways according to the historical, socioeconomic and legal context and the powers of the relevant actors. In each society the definition of the responsibilities the different actors and in particular companies should take (Wartick and Wood, 1998) emerges as a result of discussions and negotiations about contents and forms of social regulation. The behavior of companies in society is constrained and enabled by "the institutions and the sticks and carrots they provide" (Campbell, 2006, p. 929). As early as 1983 Mintzberg identified a range of possible ways a society could obtain the kind of behavior it desired from businesses, and he arranged them in the form of a "conceptual horseshoe" $(1983$, p. 529) to position the two extremes at the end of the continuum closer to each other than to the moderate positions in the middle. One end of the horseshoe represents a complete control by the state via nationalization of companies, while the other represents a complete control by the shareholders. Between these two extremes there are various other potential ways of influencing corporate behavior to fulfill the desired responsibilities, ranging from state regulation through laws to fiscal incentives over empowering stakeholders or relying on their pressure. To understand the context into which the concept of CSR entered in Germany, it is helpful to see which parts of the conceptual horseshoe have been chosen to shape business behavior in society.

The idea that business bears social responsibilities is a long-standing feature of German culture. Indeed, the notion that companies have responsibilities in society reaches back throughout the process of industrialization in Europe. Utopian philosophers and social critics shaped this thinking, as did philanthropists and proponents of the enlightened self-interest of business (Segal, 2003). In the absence of state welfare provisions, companies played a central role in assuring the well-being of their employees and families, as well as the local community. From the outset, a mix of motives spurred employers to invest in society: religious and ethical beliefs, a concern for employee loyalty, 
as well as the fear of revolts and radicalism. When, at the end of the nineteenth century, the government introduced (and later expanded) social benefits, the distribution of roles and responsibilities for social needs shifted from the private to the public sector. In general business was seen as mainly contributing financially via taxes and/or contributions to social security systems, while the public authorities were increasingly expected to deliver social benefits and services.

The German model of a coordinated or "social market economy" that developed after World War II also encompassed responsibilities of corporations in society. The social market economy is built on a strong ethical claim, namely that "it provides an institutional framework that permits the symbiotic fulfillment of complex individual and societal goals better than any other economic system" (Soltwedel, 1994, p. 35, our translation). This model is based on a mix of social regulation, relying on strong interventions by the State, a shared responsibility of the public and the private sector in providing vocational training (duale Ausbildung), and a deep involvement of the representatives of labor in the management decisions within the companies. These options correspond to "regulation" and "democratization" in Mintzberg's conceptual horseshoe. It is symptomatic of the predominantly non-adversarial nature of the relationship that the actors are referred to as social partners (Sozialpartner). In this spirit, a key feature of Germany's codetermination (Mitbestimmung) on the corporate level as well as on the shop floor is the commitment to resolving conflicts in a peaceful manner and in a "trusting relationship" (Friedenspflicht, vertrauensvolle Zusammenarbeit). Given this context, for a long time there was little need nor space for other forms of social regulation in Mintzberg's conceptual horseshoe, such as the ones based on voluntary commitments by the owners or on stakeholder pressure that characterize the CSR concept in Anglo-Saxon cultures. Numerous aspects of the CSR discourse that are considered discretionary in the United States or UK are mandated by law in Germany, and many fall under the auspices of codetermination.

The way responsibility has been understood and practiced in the German social market economy differs from the Anglo-Saxon approach because of the strong corporatist tradition of negotiating standards and conditions, often between associations representing employers and trade unions, or in tripartite mode including the state (Habisch and Wegner, 2005). The substance of German traditions and practices relating to those responsibilities also differs from the Anglo-Saxon concept of CSR. The term "social" in English refers primarily to the external community in which the company operates; by contrast, in German (and French) it refers to the community of employees. This is probably one of the reasons that German business tends to prefer the term "Corporate Citizenship" or "Civic Engagement" to describe its voluntary activities in society, rather than referring to external commitments as "social" responsibility."

This does not mean, however, that global trends in the development of CSR and the perspectives of proponents and critics in business, policymaking, and civil society have passed Germany by unnoticed. The traditional model of social regulation is being challenged and new issues are emerging with the intensification of global competition. One of the significant changes in the socioeconomic landscape in Germany is the weakening of the unions as a result of a drop in membership and a growing perception that they are blocking rather than contributing to modernization processes. An additional weakening factor is that the scope of application of the collective agreements has been reduced as ever more employers have withdrawn their membership from the employers' association that negotiates the binding agreements (Bispinck, 2003; Schmierl, 2003). A further significant change in the German landscape has been the successive reduction of 
corporate taxes and employer contributions to social security systems in the struggle to retain jobs and attract investors, shifting costs asymmetrically to employees and citizens (Schratzenstaller, 2004). The cumulative impact of these various developments has been to increase the gap between rich and poor, between those members of the population who have jobs and those who do not, between winners and losers in society. The dissatisfaction with these trends is putting the search for a new balance between economic and societal needs as described by Mintzberg's conceptual horseshoe onto the agenda once more.

\section{Two phases of "muddling through" CSR in Germany}

The concept of CSR entered the German discourse in two phases, and the process has been one of "muddling through" rather than clearly planned and strategically organized: In the first phase during the 1970s, German academics who had worked in the USA brought the idea back and launched experiments with companies like Deutsche Shell and STEAG (Dierkes, 1974, 1984). A foundation for business and society (Stiftung Gesellschaft und Unternehmen) sought to activate companies and the media to take up and develop CSR. The developments in Germany attracted international attention because the approach taken by pioneer companies was quite comprehensive in its coverage of responsibilities (Task Force on Corporate Social Performance, 1979). Compared with other European countries, German companies were early in paying attention to the impact of business activities on the natural environment (Preston et al., 1978). The participating German companies recognized the importance of developing new forms of reporting on their activities and the impacts of these activities. A working group on corporate social reporting was established and companies tried out various models using quantitative and qualitative data to track changes over time. The most advanced model was "Goal Accounting and Reporting" that highlighted the need to establish goals, ideally in dialogue with key stakeholder groups inside and outside the corporation, and then to measure results accordingly. However, interest in experimentation ebbed after the mid-1980s, when the small group of pioneer companies did not expand any further. There was some debate about whether it was time for the government to step in and mandate corporate social reporting based on the lessons learned from the experiments (Dierkes and Berthoin Antal, 1986). But there was little societal recognition, let alone (Re)discovering the Social Responsibility of Business in Germany 289 pressure, in this direction. Furthermore the agenda shifted to a new Anglo-Saxon import that focused corporate attention on the interests of a single stakeholder, namely, "shareholder value."

Interestingly, the closely related topic of "business ethics" has also surfaced cyclically in Germany, but not exactly at the same times as the discussions focused on CSR. The late 1980s, early 1990s saw such a rise in explicit attention to business ethics that observers commented "it is apparently once again modern and fashionable to talk about business ethics. The large numbers of events, speeches and publications, as well as declarations from top management in companies during the past few years is striking evidence for this fad. No business section of newspapers that claim respectability can afford to do without a series on ethics" (Dierkes and Zimmermann, 1991, p. 17, our translation). One outcome of this wave of interest may be seen in the establishment in Germany of the global civil society organization, Transparency International, in 1993. Beyond this internationally oriented activity, however, these discussions and publications left little trace on discourse and practice of business ethics in Germany subsequent years, as surveys show (Ulrich et al., 1996). 
Some 30 years later the topic of CSR returned, with the momentum for this second phase coming primarily from international initiatives. The European Commission's Green Paper on CSR in 2001 and the Multi-Stakeholder Forum sparked interest in German companies, academia and other organizations (for a detailed review see Loew et al., 2004). The European Commission specifically identified CSR as one of the means to meeting the economic, social and technological challenges of society (European Commission, 2001). The European Commission (2006) recognized that new, multi stakeholder approaches to problem-solving are needed, requiring learning and the creation of knowledge. It called on policymakers, business, and representatives of civil society to bring their expertise and their perspectives to the table and to develop instruments together at the European, national and local levels. Learning to renew the meaning of social responsibility in a globalizing world and putting CSR into practice is of course only a single strand in an overall process of social and economic renewal, a process that depends on the ability of the diverse actors to work together to address different and often conflicting goals and values.

The publications and initiatives launched by other international organizations such as the United Nations and the OECD also contributed to the renewal of interest in CSR in Germany. Some German companies and business organizations as well as unions and NGOs started to engage in these international activities like the United Nations Global Compact iiito develop a shared understanding and practice of CSR. German multinational companies were for example among the first to start concluding international framework agreements on CSR in the 1990s, but they gradually ceded this opportunity to shape the agenda. The more recent and innovative agreements have been initiated by multinationals from other countries, especially France (Sobczak, 2008). Overall, German actors did not take the lead in shaping the way problems are addressed and desirable outcomes are defined in these fora (Backhaus-Maul et al., 2008). Moreover, there is little evidence of a coordinated feedback of their international experiences into the German debate.

The contribution of German scholars to the development of the CSR discourse has been fragmented as well. In the 1970s and early 1980s only a handful of scholars conducted research in this area. Far greater numbers of academics entered the field in the late 1990s and after the turn of the century in universities and in special research institutions. However, unlike their counterparts in the AngloSaxon context, most scholars entering the field in Germany in this period had little or no awareness of the work that had been conducted in earlier decades. "B By overlooking the extent of "implicit" CSR in Germany, they mistakenly saw the country as a blank spot on the CSR landscape (Habisch and Wegner, 2005, p. 11). The formation of an epistemic community with a cumulative, shared body of knowledge in this multidisciplinary field has been slow in the absence of three kinds of professional institutions that have been significant in other countries. Germany does not have business schools or think tanks that focus on such issues. Nor has there been a core professional forum like the Social Issues in Management Division in the Academy of Management. The result of this gap between the first and the second influx of CSR in Germany is inefficient learning. Academia has contributed little to 290 Ariane Berthoin Antal et al. learning from the earlier experiences with CSR. The second explicit entrance of CSR has indeed embedded the topic in German business and academia more broadly than during the first phase, but the activities are fragmented and lacking in overall strategic orientation.

Despite the absence of strategic leadership, a wide range of CSR-related activities and initiatives multiplied in Germany over the past decades, indicating a growing interest in and demand for the 
social responsibility of business. The roots of these activities lie in different areas of societal concern and activism identified in Mintzberg's conceptual horseshoe under the label of stakeholder pressure. First and foremost, the environmental movement became a social and political force in Germany in the 1970s, earlier and more effectively than in other European countries, including the establishment of the Green Party. These developments not only led to the introduction of environmental legislation, they also spawned a wide range of collaborative and conflictual exchanges between civil society, policymakers and the private sector. For example, the UN-sponsored initiative for sustainable development "Agenda 21" spawned projects in over 2600 municipalities in Germany. The country was the recognized leader in environmental policy in Europe and a pioneer in the formulation of standards for sustainable management and consumption. German companies initially took the lead in developing corporate environmental reporting and eco-accounting, but in recent years companies in other countries have become more innovative and German models have changed very little (Berthoin Antal and Sobczak, 2005).

Labor market concerns, too, stimulated the demand for corporate responses. Observing the rise in mass unemployment and the concomitant dearth of entry-level training opportunities for highschool graduates, and the failure of traditional corporatist attempts by unions and employer associations to find solutions, public policymakers called directly on the private sector to protect employment and to create new jobs and apprenticeships. A wide range of cooperative ventures and partnerships were created to generate work and training opportunities. Examples include the "Initiative für Beschäftigung" (Initiative for Employment) that was launched by leading figures in business and unions, and the Germany-wide model project "Unternehmen: Partner der Jugend" (Companies: Partners of Youth; Wendt, 2000). Such initiatives stimulated the generation of new solutions and innovative offers by subsidizing coordinators who helped put in place cooperative ventures between local organizations for youth and social work and the private sector, usually small and medium-sized companies. Furthermore at the local and regional level numerous employment agreements and action plans were developed and implemented in organizations composed of public and private sector actors, often with financial support from the European Union.

The "Initiative Neue Qualität der Arbeit" (Initiative New Quality of Work) is an example of activities resulting from a third trigger for redefining the role of business in society in Germany. This joint project by the Federal Government, state governments, employers, and unions is a vehicle for finding new responses to the significant changes underway in work and society. The aging of the labor force, technological developments, and the pressure of globalizing markets on labor standards require innovative solutions beyond the established negotiation procedures between employer organizations and unions, and beyond existing regulatory means of protecting health and safety at work.

A further factor that influenced the redefinition of roles and responsibilities in business and society in recent decades in Germany has been the movement towards the concept of "aktivierender Staat," whereby the government maintains its responsibility for dealing with core societal issues but activates other actors to participate in providing the necessary services (Oppen, 2005; Oppen et al., 2005). This partnership approach between the public and the private sector and civil society organizations underpins numerous regional and municipal development programs. The most prominent such program is the initiative "Soziale Stadt" (Social City), under the joint auspices of federal and state-level authorities. This initiative includes a platform (called "Entwicklung und Chancen" - Development and Opportunity) for establishing youth projects in disadvantaged city 
districts. The intention is to break and reverse the negative spiral of unemployment, poverty, social exclusion, and violence. The idea is to build social capital and strengthen the development potential in these places by engaging in cooperative ventures that (Re)discovering the Social Responsibility of Business in Germany 291 draw on the combined resources and competences of all local actors, including the private sector (Nerlich and Kirchberg, 2001).

Last but not least, there has been an increase in the number of individual companies - medium sized companies as well as large multinationals - engaging in social projects together with local authorities and social organizations under the banner of "Corporate Citizenship" (Backhaus-Maul et al., 2008; Maaß and Clemens, 2002; Oppen, 2005). This voluntary add-on to business activities is seen as a way that business can give back to society. Companies have "invested" socially by providing material and personnel resources as well as know-how for dealing with problems in the areas of education and training, health and housing, for example. Such "corporate citizenship" projects may well help the specified target groups while also improving the reputation of the companies involved, but most of them are not integrated into the corporate strategy and they do not affect the way the company produces and delivers its goods and services (CCCD, 2007). A further drawback from the point of view of societal policy is that such projects are not developed systematically to meet the most pressing social needs. Instead, issues are selected in accordance with the message the company wishes to send to the market. While giving back to society may be an integral part of the corporate identity or culture, it tends to be managed separately from the corporate strategy, so it is not necessarily an indicator of a new, socially and environmentally sustainable way of managing companies (Oppen, 2005). Corporate citizenship in Germany is currently based on the implicit understanding that business should invest in the community when it is doing well and can afford the resources, and that "extra-curricular" activities can be dropped when business is not doing so well. The commitment therefore usually takes the form of projects with a short to medium-term time frame. Recent years have seen the multiplication in Germany of symposia and competitions to promote corporate citizenship and to improve the quality of activities by diffusing "best practices." For example, in 2002 employer confederations and the business weekly "Wirtschaftswoche" launched the prize for "Freedom and Responsibility" (Freiheit und Verantwortung) under the auspices of the President of the Federal Republic of Germany. It is impossible to provide a complete and reliable overview over the multiplicity of CSR-related activities currently in place in Germany. There are only collections of case studies to refer to and non representative surveys. A recent Europe-wide survey concluded that, compared with their European counterparts, German companies have a lot to learn (Kröher, 2005, p. 80). They rank low on integrating their social engagement into business decision making and on the transparency of their reporting. Another review conducted in Germany in 2007 revealed that still only a third of the major German companies produce any kind of CSR report (Gebauer and Westermann, 2007). A careful examination of the quality of reports reveals that areas that have been traditional strengths of German companies, such as product safety, employee benefits, and environmental standards, are generally reported on thoroughly and clearly. However, topics that are newer for the German understanding of social responsibilities, such as tax compliance, subsidies, transnational supply chain management, anticorruption measures, and stakeholder consultation receive little or no coverage even if some progress has been made in the last 2 years (Gebauer and Westermann, 2007; Loew et al., 2005).

\section{The outlook for CSR in Germany: beyond muddling through}


Given this track record of diverse, fragmented and uncoordinated initiatives and inefficient learning over the past decades, the future development of business society relations in Germany is likely to continue being a process of muddling through, unless a conscious choice is made for a different approach. To date no platform has been established in Germany, parallel to the Multi-Stakeholder Forum at the European level, at which members of diverse organizations could develop a shared sense of what needs to be done and how best to tackle the issues. Nor does there appear to be an integrating driving force in Germany, such as that generated by the government in Sweden or the Netherlands, or by the Copenhagen Center, a Danish think tank, to mobilize and bundle together the diverse actors, discourses, and activities (Enquetekommission "Zukunft des bürgerschaftlichen Engagements "2002).

The weak engagement of the German government in the international and domestic CSR discourse is particularly striking in comparison with other European countries like France, the UK, and Sweden, where the topic has taken on strategic significance (Bertelsmann Stiftung, 2006). Neither at the national nor at the local level are public policymakers in Germany taking a leading role. Although Germany subscribed formally to the OECD Guidelines for Multinational Corporations, the government has done much less than other countries to ensure that the guidelines are publicly promoted and put into practice. Nor has the government established comprehensive and transparent complaint procedures (OECD Watch, 2005). Policymakers are leaving the learning process to the sharing of examples of good practices and to dialogues between local actors from business and NGOs rather than seeing themselves as strategically contributing to shaping the agenda and practices. Policymakers in Germany generally share the business view that CSR should be voluntary. Therefore, instead of using regulatory options to stimulate performance, as has happened in France, the German government is relying on measures such as voluntary labeling of products, arguing that companies are thereby encouraged to "market their engagement for society" (Bundesregierung, 2002, p. 3, our translation). Nor has public administration shown an inclination to stimulate CSR by serving as a role model itself in the market. Unlike their counterparts in Britain, the Netherlands and France, and contrary to EU guidelines, public authorities have not yet integrated principles of CSR into their purchasing decisions for products and services, nor into their investment decisions.

The lack of coordination and strategic orientation inherent in muddling through has costs for the overall system The diverse range of activities that companies and their partners engage in, often with a great deal of energy and commitment, undoubtedly lead to certain local improvements. However, the uncoordinated activities may in sum contradict rather than support and complement each other. The overall outcome is left to chance; there is no systematic attempt to collect empirical evidence to identify and assess the effects of CSR on society. Individual organizations or partners may learn in the process of trying out their ideas, but the various actors learn too little from the multiplicity of experiments underway, leading to costly mistakes or the unnecessary reinventing of the wheel in different locations. The system as a whole does not stimulate organizational learning, nor does it benefit from the learning that happens to occur in different places, in Germany as well as abroad.

If Germany continues to pursue a "muddling through" approach to CSR, the country will be a passive recipient rather than a shaper of international trends. German organizations and citizens will then have to adapt to standards and practices that have been developed to suit conditions and mindsets in other countries whose representatives have been active in the various fora. This is a relatively 
probable scenario because there are no strong indicators to suggest that Germany will break out of the muddling through mode in the coming years.

In order for German actors to regain the ability to agree on procedures and standards they believe are good for the future of the country, a proactive approach is needed that brings the diverse stakeholders together to explicate different goals and competing values, formulate priorities, decide on actions, and agree on processes of monitoring and evaluation. Although there are definitely experiences to build on from the past years, the wide-scale interorganizational learning that is needed will require intentional experimentation with multiple actors at the local, regional, and national level, as well as an active engagement in negotiations with nongovernmental actors and other countries. The German Council for Sustainable Development has explicitly recognized the need for such active experimentation, as well as the fact that significant improvements cannot be achieved by any single actor, nor any one approach (Rat für Nachhaltige Entwicklung, 2006, p. 16).

Moving out of muddling through mode would require the various actors in Germany to change their approach. First, they would need (together with organizations in other countries) to actively contribute to the development of a broader concept than "CSR" that takes into account changing expectations and constellations of actors. Second, German organizations would need to engage in organizational and interorganizational learning by exploring the potential of intentional experimentation in this field.

\section{From CSR to global responsibility}

Unfortunately, the very concept of CSR impedes the development of new ideas and practices. Some writers therefore prefer to speak of CSR as a forum for advocating conflicting interests, a site of "contestation for the right to determine social objectives and the funding of these objectives" (Michael, 2003, p. 123), as system dynamics rather than a distinct phenomenon (Zadek, 2004, p. 27). We agree with the emphasis on interactivity and suggest that the term CSR should be replaced by a more inclusive one that recognizes that all types of organizations should be held responsible for multiple aspects of performance and in diverse locations: Global Responsibility (Berthoin Antal and Sobczak, 2004). The traditional way of thinking about the roles and responsibilities of actors in CSR is too limited.

First, the focus on business, the " $C$ " in CSR, is too narrow, because it positions corporations at the center as the source of problems and solutions, thereby essentially relegating all other non business actors to the grandstands. A broader view is required that positions all types of organizations as actors whose behavior has social, economic, and environmental impacts for which they are accountable to their particular set of stakeholders. The analytical framework must therefore be redefined to enable the constellation of actors to be examined from several perspectives, revealing their multiple roles and their interdependencies in a more balanced way. Depending on the chosen angle of examination, at any point in time, in any given situation, a company, an NGO, a consumer association, or a public service provider, for example, may be examined as a "focal organization" surrounded by its relevant stakeholders, or as a stakeholder of another "focal" organization.

The second limitation to overcome in order to develop a more balanced approach is that the " $\mathrm{S}$ " in CSR gives primacy to one aspect, namely the social/ societal impact. The economic and environmental performances of organizations are equally significant for their future existence and 
for the health of society. Concepts like the Triple Bottom Line and instruments like the GRI recognize this fact, but the term CSR does not. The challenge for corporations as well as every other kind of organization is to keep seeking ways of achieving the best possible result in all dimensions. The challenge is twofold: organizations must attend to these multiple dimensions in the course of their own performance, i.e., in their behavior as "focal" organizations, as well as in their interactions as stakeholders of other "focal" organizations.

The concept of "CSR" must therefore be replaced by one that reflects that the system consists of multiple actors who bear responsibility for the impacts of their activities. A more appropriate concept is "Global Responsibility" (Berthoin Antal and Sobczak, 2004), because the word "global" encompasses different types of actors rather than focusing on companies; it includes responsibilities for aspects of performance beyond the social; and it recognizes the boundary-crossing nature of many activities and issues threatening the overall health of societies. Whether an organization is in the public or the private sector, engaging in Global Responsibility entails learning together with its stakeholders to enhance the long-term vitality of the organization while conducting all its activities in such a way as to strengthen their relations with their social, economic, and natural environment and to reduce the negative impacts.

When the challenge of preparing for the future is tackled from the perspective of Global Responsibility, the need for open dialogue to understand issues and work out solutions together from different perspectives takes center stage. Simply finger-pointing at companies from a safe distance is no longer an option, nor is demanding that government regulate a problem away, nor is exerting pressure for shareholder value to increase at the expense of all other interests. Deriving the greatest possible benefit from negotiating the means and ends of global responsibility will require changes in approaches and role definitions of trade unions, NGOs and other social organizations as well. They cannot just demand more responsibility from others without taking on more themselves, for example in their relationships with their diverse constituencies and society at large. By experimenting with ways of putting global responsibility into practice in their own operational contexts, such actors will be more legitimized to monitor the progress made by others, to understand the difficulties entailed in pursuing multiple goals, and to identify opportunities for improvement (Michael, 2003).

For German public authorities to achieve Global Responsibility would require that they move beyond encouraging the private sector to undertake activities and then facilitating the exchange of best practices. It would entail them trying out new ways of acting on the market. As employers and purchasers of goods and services, public authorities have the opportunity - and the responsibility to develop decision-making processes that take social, economic, and environmental considerations into account in a balanced way. For example, although the government has called on corporations to include social and environmental considerations into their business decisions, its own decisions (e.g., human resources and contracting out) are being subjected increasingly to crude cost calculations and the principle of competition. This would also mean correcting the development course the public sector is engaging in under the banner of "New Public Management." Instead of imitating narrow business management skills, it needs to develop a much broader approach. Seen positively, the public sector could build in new ways on its traditional strengths of ensuring inclusion and fairness. 
Thus, engaging with Global Responsibility helps move the discourse about business and society out of the purely managerial realm by recognizing the political nature of the issues and processes involved (Bendell, 2005; Blowfield, 2005). This perspective is oriented towards re-embedding all organizational actors into the social sphere and building relationships between them. The shift towards defining and achieving potentially competing goals in a compatible and balanced manner between different actors implies undertaking not simply organizational learning, but interorganizational learning in a coordinated manner.

\section{Intentional experimentation}

Putting Global Responsibility into practice requires intentional experimentation by all actors. Intentional experimentation is qualitatively different from the fragmented muddling through characteristic of Germany in recent years. It entails a concerted effort in society to learn from its activities across the spectrum of societal issues and with the participation of many different kinds of organizations. It is not enough, for example, for isolated public-private partnerships to surface here and there at will. Learning how to negotiate ambitious, achievable objectives for global responsibility for themselves in collaboration with other actors will be a key asset for organizations seeking to enhance Germany's social, economic, and environmental quality levels in a globalizing context.

The following two examples serve to illustrate how German actors could build on their specific assets and on relevant experiences to engage in intentional experimentation. The first example highlights the way the tradition of social partnership between companies and workers' representatives may be a fruitful field for intentional experimentation in defining and implementing shared standards of responsibility in a global context and position Germany as a leader in this domain. The second example relates to the development of innovative ways of reporting on global responsibility and illustrates how Germany could build on experiences from the past to shape the international debate on this crucial aspect within the CSR arena.

- International framework agreements on Global Responsibility negotiated between multinational companies and global union federations are an innovative way of involving a key stakeholder - the employees - in the process of defining the companies' social and environmental responsibilities and in the implementation and monitoring of the related policies. These agreements differ from unilateral codes of conduct in their content insofar as the negotiation with the workers' representatives usually leads to a reference to the ILO core conventions and to the definition of a scope of application including the plants of the company's suppliers and subcontractors. But even more importantly, these agreements document the common interest for the idea of Global Responsibility and the signatories' willingness to consider it as a field of cooperation rather than of confrontation. German social partners can build on the tradition of the peaceful resolution clauses in social dialogue which require them to resort to conflict and strike only after all other approaches have been tried. International framework agreements also have the potential to create a joint process between the management and the workers' representatives (Re)discovering the Social Responsibility of Business in Germany 295 and thus to develop their common ownership of the agreement and their shared responsibility for the company's impact on its natural and social environment. The first two such agreements were initiated by French organizations in the late 1990s, but then after the turn of the century, German companies and their European Works' Councils (EWC) and unions took the lead in negotiating such agreements, with 17 of the 62 existing agreements 
signed by multinationals headquartered in Germany (European Commission, 2008). The metalworkers' union, IG Metall, was particularly active in this field and clearly influenced the standard content of such agreements, as well as the choice of the actors involved in their negotiation and their implementation. The past 3 years, however, have witnessed fewer agreements signed in Germany, and the most innovative ones have been negotiated with French companies (Sobczak, 2008). The German social partners may want to reconsider their strategy: instead of stopping exploring this new form of social dialogue they could analyze what they could learn from recent developments in other countries. Developing intentional experimentation in this field would, for example, mean for the German companies and trade unions to take an active part in the current debate at the European level on a potential legal framework for transnational collective bargaining (Ales et al., 2006); to share their experiences with actors from other countries; and to promote their specific approaches in this area, such as the almost systematic involvement of European Works Councils in the negotiation of these agreements. ${ }^{\mathrm{vi}}$

- A second example of how to build on the experiences of co-regulation and co-management in setting and enforcing standards is in the area of reporting on performance for global responsibility. Much time and expertise has been invested for more than a century to develop financial reporting methods, and improvements continue to be sought, particularly after the spectacular financial scandals of recent years. Compared with this long history, experiments with methods for reporting on other aspects of organizational performance started only relatively recently, some three decades ago. Nevertheless, quite a bit of progress has been made, including methods to combine the different aspects of global responsibility, for example into the so-called Triple Bottom Line (Elkington, 1998). German companies took a lead in the early years (i.e., 1970s and 1980s), but then essentially left the initiative to others. In order to stimulate a much greater number of organizations in different spheres of society to take up their global responsibilities, Germany could now choose to take advantage of what has been developed to date by establishing a mandatory reporting requirement, specifically for "interactive goal accounting and reporting" (Berthoin Antal et al., 2002). The distinctive aspect of this method is that it starts at the beginning of the goal-setting process and stimulates stakeholder interaction from the outset. Introducing such a requirement would entail providing a framework rather than prescribing detailed reporting rules that would lock the reporting method into the current state of the art. Instead, the requirement should focus the attention of organizations on processes for formulating ambitious, realistic objectives for global responsibility in conjunction with their particular constellation of stakeholders and identifying useful indicators for monitoring performance. The actors negotiating appropriate criteria could of course benefit from recent developments such as the GRI, ISO, and the Global Compact. The interactive approach makes the political aspect of the process evident to the participants, so that they can avoid the trap of drawing on these elements as a purely technical-instrumental exercise.

\section{Conclusion}

Putting Global Responsibility into practice in Germany would mean that organizations in the public and private sectors, as well as in civil society, would need to develop the skills for managing the process in their multiple roles - as focal organizations and as stakeholders of other organizations. This would entail embedding global responsibility into organizations' strategies, rather than treating it as an add-on activity. To the extent that organizations would build up experience figuring out how best to formulate objectives with their own stakeholders and how to report on performance, they 
would be less likely to hold unreasonable expectations of others. Equally importantly, the actors involved would know that smoke screens put up to try to get away with low objectives and poor performance would be easily detected by stakeholders.

Intentional experimentation would also have implications for how the German state fulfills its regulatory functions. Instead of conceiving its main activity as defining binding decisions and detailed standards that lock practices in at a fixed level, the state would need to learn how to stimulate continuous learning among all actors concerned (Siebenhuener et al., 2006). One way would be to build in milestones for reviewing the learning from experiences so that adjustments can be made, beyond the well-established evaluation practices that focus on the efficiency of project and program management. Whereas the benefits for corporations are widely recorded (Margolis and Walsh, 2003; Orlitzky et al., 2003) an assessment is missing of the societal impacts of the combination of activities undertaken to improve Global Responsibility.

Intentional experimentation also means developing the institutional capacity to reflect on what can be learned from experiences with the profusion of separate CSR-related standards that has grown, mostly through self-regulation in different economic sectors, over the past years. In other words, in this domain it is less a matter of stimulating experimentation but rather of reaping the benefits from the "natural laboratory" that has emerged in an unplanned and uncoordinated manner. No "onesize-fits-all" approach to regulation and standard setting is possible or desirable, but the current conditions are not suited to enabling well informed decisions. The jungle of standards makes it extremely difficult for stakeholders to understand, monitor, and compare performance criteria. By working with other organizations (e.g., industry associations, unions, environmental groups), German public authorities would be able to exploit the diversity of learning experiences and bring greater coherence and clarity in this area.

Undertaking intentional experimentation for Global Responsibility would help Germany break out of its muddling through mode as well as out of its relative abstinence from shaping the international discourse on the role of business in society, and more specifically on principles and practices of CSR. As has been shown in the field of technological innovation, there is a potential advantage to the second mover status, because the mistakes and dead ends of the leaders do not have to be repeated. The second mover can leapfrog over some hurdles and achieve the desired ends faster and with lower costs. This learning principle applies to social innovations as well. Germany could benefit from analyzing and drawing out the results of interorganizational learning at the local, regional, and national level. With time it could thereby regain influence in negotiations with other governments and with nongovernmental organizations. It could bring in fresh ideas and speak authoritatively about the advantages and disadvantages of different approaches. A step in this direction would be for the German government to expand on the tradition of social partnership and ensure that representatives of civil society are formally integrated in multi-stakeholder processes, rather than legitimizing decisions made solely with powerful business interests. Another way of building on German tradition in a progressive manner would be to stimulate the development of critical expertise to ensure that various stakeholders have access to the necessary information to participate knowledgeably in setting standards and monitoring performance. This approach was a significant factor in the effectiveness of environmental NGOs in Germany, because very early they recognized the importance of having their own sources of expertise (such as the Institut für ökologische Wirtschaftsforschung and the Öko-Institut). 
The overall outcome for Germany of intentional experimentation for Global Responsibility cannot be defined in detail in advance. It will emerge from the conscious choices made and the coordinated dialogue between diverse actors, from the conclusions these actors draw out of experimental experiences, and from the corrective action they take to reflect their learning along the way. The likelihood that mistakes will be made in the process, that certain (Re)discovering the Social Responsibility of Business in Germany 297 activities will fail, that new problems will arise, is high. Such outcomes are the stuff of learning, but in Germany the tolerance of failure as the source of learning seems to be comparatively low, penalizing or stigmatizing those who make errors. In order to support and benefit from organizational learning towards Global Responsibility, it is therefore essential that a system-wide shift be stimulated that encourages experimentation and learning from failures as well as successes.

\section{References}

Ales, E., S. Engblom, T. Jaspers, S. Laulom, S. Sciarra, A. Sobczak and F. Valde's Dal-Re': 2006, 'Transnational Collective Bargaining: Past, Present and Future', Report to the European Commission, Brussels.

Argandon a, A.: 2004, 'Economic Ethics and Institutional Change', Journal of Business Ethics 53(1-2), 191-201.

Backhaus-Maul, H., C. Biedermann, S. Nährlich and J. Poterauer: 2008, 'Corporate Citizenship in Deutschland. Die überraschende Konjunktur einer verspäteten Debatte' [Corporate Citizenship in Germany. The Surprising Rise of a Late Debate], in H. Backhaus- Maul, C. Biedermann, S. Nährlich and J. Poterauer (eds.), Corporate Citizenship in Deutschland. Bilanz und Perspektiven [Corporate Citizenship in Germany: State of the Art and Perspectives for the Future] (Verlag für Sozialwissenschaften, Wiesbaden), pp. 13-42.

Bendell, J.: 2005, 'In Whose Name? The Accountability of Corporate Social Responsibility', Development in Practice 15(3-4), 362-374.

Bertelsmann Stiftung: 2006, Partner Staat? CSR-Politik in Europa [The State as a Partner? European CSR Policy] (Bertelsmann Stiftung, Gütersloh).

Berthoin Antal, A., M. Dierkes, K. MacMillan and L. Marz: 2002, 'Corporate Social Reporting Revisited', Journal of General Management 28(2), 22-42.

Berthoin Antal, A., M. Dierkes and M. Oppen: 2007, 'Zur Zukunft der Wirtschaft in der Gesellschaft: sozial verantwortliche Unternehmensführung als Experimentierfeld' [The Future of the Economy in Society: Corporate Social Responsibility as an Experimental Ground], in J. Kocka (ed.), Zukunftsfähigkeit Deutschlands - Sozialwissenschaftliche Essays. WZB-Jahrbuch 2006 (edition sigma, Berlin), pp. 267-290.

Berthoin Antal, A. and A. Sobczak: 2004, 'Beyond CSR: Organizational Learning for Global Responsibility', Journal of General Management 30(2), 77-98. 
Berthoin Antal, A. and A. Sobczak: 2005, 'Von Sozialbilanzen zu Nachhaltigkeitsberichten: Wie Deutschland wieder zum Vorreiter wird' [From Corporate Social Accounting to Sustainability Reports: How Germany Can Regain the Lead], Personalführung 6, 74-85.

Bispinck, R.: 2003, 'Das deutsche Tarifsystem in Zeiten der Krise - Streit um Flächentarif, Differenzierung und Mindeststandards' [The German Tariff System in Times of Crises - Disputes Over Tariffs, Differentiation and Minimum Standards], WSI-Mitteilungen 56(7), 395-404.

Blowfield, M.: 2005, 'Corporate Social Responsibility - The Failing Discipline and Why It Matters for International Relations', International Relations 19(2), 173-191.

Bundesregierung: 2002, Stellungnahme zum Gru"nbuch der Kommission "Europäische Rahmenbedingungen für die soziale Verantwortung der Unternehmen" KOM (2001), 366 ENDG [The Position of the Federal Republic of Germany on the CSR-Greenbook of the EU Commission], http://ec.europa.eu/employ ment social/soc-dial/csr/pdf2/013-GOVNAT Deutsch land Germany 020131 de.pdf. Accessed Aug 2006.

Campbell, J. L.: 2006, 'Institutional Analysis and the Paradox of Corporate Social Responsibility', American Behavioral Scientist 49(7), 925-938.

CCCD (Centrum für Corporate Citizenship in Deutschland): 2007, Corporate Citizenship. Gesellschaftliches Engagement von Unternehmen in Deutschland und im transatlantischen Vergleich mit den USA. Ergebnisse einer Unternehmensbefragung des CCCD [Corporate Citizenship. Results of a Corporate Survey Comparing Corporate Citizenship in Germany and the USA] (CCCD, Berlin).

Clarke, M. and J. Stewart: 1997, 'Handling the Wicked Issues - A Challenge for Government', INLOGOV Discussion Paper, Institute of Local Government Studies, Birmingham.

Crook, C.: 2005, 'The Good Company. A Sceptical Look at Corporate Social Responsibility', The Economist 22, 3-18.

Dierkes, M.: 1974, Die Sozialbilanz - Ein gesellschaftsbezogenes Informations- und Rechnungssystem [The Social Account - A Societal Information and Accounting System] (Herder \& Herder, Frankfurt/Main).

Dierkes, M.: 1984, 'Gesellschaftsbezogene Berichterstattung. Was lehren uns die Experimente der letzten 10 Jahre?' [Societal Reporting: What Do the Experiments of the Past 10 Years Teach Us?], Zeitschrift für Betriebswirtschaft 54(12), 1210-1235.

Dierkes, M. and A. Berthoin Antal: 1986, 'Whither Corporate Social Reporting: Is It Time to Legislate?', California Management Review 28(3), 106-121.

Dierkes, M. and K. Zimmermann: 1991, 'Unternehmensethik: Mehr Schein als Sein?' [Business Ethics: How Much Substance?], in M. Dierkes and K. Zimmermann (eds.), Ethik und Geschäft. Dimensionen und Grenzen Unternehmerischer Verantwortung [Ethics and Business. Dimensions and Limits of Corporate Responsibility] (Gabler Verlag, Wiesbaden), pp. 15-69.

Doane, D.: 2005, 'The Myth of CSR', Stanford Social Innovation Review, Fall, 23-29. 
Elkington, J.: 1998, Cannibals with Forks: The Triple Bottom Line of the 21st Century Business (New Society Publishers, Gabriola Island).

Enquetekommission "Zukunft des bürgerschaftlichen Engagements": 2002, Bericht. Bürgerschaftliches Engagement: auf dem Weg in eine zukunftsfähige Bürgergesellschaft [The Future of Citizen-Action Endeavours] (Leske + Budrich, Opladen).

European Commission: 2001, Green Paper on "Promoting a European Framework for Corporate Social Responsibility" (European Commission, Brussels).

European Commission: 2006, Implementing the Partnership for Growth and Jobs: Making Europe a Pole of Excellence on Corporate Social Responsibility (European Commission, Brussels).

European Commission: 2008, Mapping of Transnational Texts Negotiated at Corporate Level (European Commission, Brussels), EMPL F2 EP/bp 2008 (D) 14511.

Gebauer, J. and U. Westermann: 2007, Nachhaltigkeitsberichterstattung in Deutschland. Ergebnisse und Trends im Ranking 2007 [Sustainability Reporting in Gemany. Results and Trends in the 2007 Ranking] (Institut für ökologische Wirtschaftsforschung und Future e.V. Berlin, Hannover), http://www.ranking-nachhaltig keitsberichte.de/pdf/2007/Ergebnisbericht_Ranking_2007_final.pdf. Accessed Dec 2008.

Habisch, A. and M. Wegner: 2005, 'Germany: Overcoming the Heritage of Corporatism', in A. Habisch, J. Jonker, M. Wegner and R. Schmidpeter (eds.), Corporate Social Responsibility Across Europe (Springer Verlag, Berlin), pp. 111-123.

Häußermann, H., M. Kronauer and W. Siebel (eds.): 2004, An den Rändern der Städte. Armut und Aus- (Re)discovering the Social Responsibility of Business in Germany 299 grenzung [Urban Peripheries: Poverty and Social Exclusion] (edition Suhrkamp, Frankfurt/Main).

Keller, B. and H. Seifert: 2006, 'Atypische Beschäftigungsverhältnisse: Flexibilität, soziale Sicherheit und Prekarität' [Atypical Employment Conditions: Flexibility, Social Security and Instability], WSIMitteilungen 59(5), 235.

Kröher, M. O. R.: 2005, 'Good Company Ranking: Tue Gutes und profitiere davon' [Good Company Ranking: Do Good Deeds and Profit from Them], Manager Magazin 2, 80-96.

Loew, T., K. Ankele, S. Braun and J. Clausen: 2004, 'Bedeutung der internationalen CSR-Diskussion für Nachhaltigkeit und die sich daraus ergebenden Anforderungen an Unternehmen mit Fokus Berichterstattung' [The Significance of the International CSR Discussion for Sustainability and the Resulting Reporting Demands on Companies], Final Report. Berlin and Münster.

Loew, T., J. Clausen and U. Westermann: 2005, Nachhaltigkeitsberichterstattung in Deutschland. Ergebnisse und Trends im Ranking 2005 [Sustainability Reporting in Germany. Results and Trends in the 2005 Ranking] (Institut für ökologische Wirtschaftsforschung und Future e.V. Berlin, Hannover), http://www.rankingnachhaltigkeitsberichte. de/pdf/Ranking_Endbericht. pdf. Accessed Dec 2008. 
Maaß, F. and R. Clemens: 2002, 'Corporate Citizenship. Das Unternehmen als "guter Bürger"' [Corporate Citizenship: the Corporation as a "Good Citizen"], Schriften zur Mittelstandsforschung Nr. 94 NF (Deutscher Universitäts-Verlag, Wiesbaden).

Margolis, J. D. and J. P. Walsh: 2003, 'Misery Loves Companies: Rethinking Social Initiatives by Business', Administrative Science Quarterly 48(2), 268-305.

Matten, D. and J. Moon: 2008, “Implicit' and 'Explicit' CSR: A Conceptual Framework for a Comparative Understanding of Corporate Social Responsibility', Academy of Management Review $33(2), 404-424$.

Michael, B.: 2003, 'Corporate Social Responsibility in International Development: An Overview and Critique', Corporate Social Responsibility and Environmental Management 10(3), 115-128.

Mintzberg, H.: 1983, Power in and Around Organizations (Prentice-Hall, Englewood Cliffs, NJ).

Nerlich, M. and V. Kirchberg: 2001, 'Social Sponsoring und Social-Investment - Unternehmerische Förderung für soziale Projekte im Quartier' [Social Sponsoring and Social-Investment - Corporate Sponsorship of Socially Beneficial Neighbourhood Projects], in M. Alisch (ed.), Stadtteilmanagement. Voraussetzungen und Chancen für die soziale Stadt (Leske + Budrich, Opladen), pp. 251-274.

OECD Watch: 2005, Five Years On. A Review of the OECD Guidelines and National Contact Points (OCDE Watch, Amsterdam).

Oppen, M.: 2005, 'Local Governance und bürgerschaftliches Engagement von Unternehmen' [Local Governance and Corporate Citizenship], in H. Bauer,

P. Biwald and E. Dearing (eds.), Public Governance. Öffentliche Aufgaben gemeinsam erfüllen und effektiv steuern [Public Governance: Jointly Fulfilling and Effectively Steering Public Responsibilities] (Neuer Wissenschaftlicher Verlag, Vienna \& Graz), pp. 342-361.

Oppen, M., D. Sack and A. Wegener: 2005, 'German Public Private Partnerships in Personal Social Services: New Directions in a Corporatist Environment', in G. Hodge and C. Greve (eds.), The Challenge of Public- Private-Partnerships. Learning from International Experience (Edward Elgar, Cheltenham, UK; Northampton, MA, USA), pp. 269-289.

Orlitzky, M., F. L. Schmidt and S. L. Rynes: 2003, 'Corporate Social and Financial Performance: A Meta- Analysis', Organization Studies 24(3), 403-441.

Palazzo, B.: 2002, 'US-American and German Business Ethics: An Intercultural Comparison', Journal of Business Ethics 41(3), 195-216.

Preston, L. E., F. Rey and M. Dierkes: 1978, 'Comparing Corporate Social Performance. Germany, France, Canada, and the U.S.', California Management Review 20(4), 40-49.

Rat für Nachhaltige Entwicklung: 2006, Unternehmerische Verantwortung in einer globalisierten Welt - Ein deutsches Profil der Corporate Social Responsibility. Empfehlungen des Rates für Nachhaltige Entwicklung [Corporate Responsibility in a Globalised World - A German Profile of Corporate Social Responsibility. Recommendations of the German Council for Sustainable Development] (Berlin), 
http://www.nachhaltigkeitsrat.de/uploads/ media/Broschuere_CSR-Empfehlungen.pdf. Accessed Dec 2008.

Schmierl, K.: 2003, 'Wird das deutsche Modell der Arbeitsregulierung die Umschichtungen in der Arbeitsgesellschaft überleben?' [Will the German Work Regulation Model Survive the Shifts in Labour Force?], WSI-Mitteilungen 56(11), 651.

Schratzenstaller, M.: 2004, 'Aktuelle Entwicklungen der Unternehmensbesteuerung im europäischen Kontext' [Current Developments in European Corporate Taxation Laws], WSI-Mitteilungen 57(12), 669.

Segal, J. P.: 2003, 'Unternehmenskulturen in Deutschland und Frankreich: Globalisierung unter angelsächsischen Vorzeichen' [Corporate Cultures in Germany and France: Globalization Under Anglo-Saxon Influences], in Deutsch-Französisches Institut (ed.), 300 Ariane Berthoin Antal et al. Frankreich Jahrbuch 2003 (VS Verlag für Sozialwissenschaften, Wiesbaden), pp. 119-136.

Siebenhuener, B., M. Arnold, E. Hoffmann, T. Behrens, S, Heerwart and T. Beschorner: 2006, Organisationales Lernen und Nachhaltigkeit [Organizational Learning and Sustainability] (Metropolis, Marburg).

Smith, N. C.: 2003, 'Corporate Social Responsibility: Whether or How?', California Management Review 45(4), 52-76.

Sobczak, A.: 2008, 'Syndicats et responsabilité sociale des multinationales' [Unions and the Social Responsibility of Multinationals], Gestion Revue internationale de Gestion 33(1), 18-26.

Soltwedel, R.: 1994, 'Normen und Institutionen - von der Sozialphilosophie zur praktischen Ethik' [Norms and Institutions - from Social Philosophy to Practical Ethics], in Bertelsmann Stiftung, Heinz Nixdorf Stiftung and Ludwig-Erhard-Stiftung, Markt mit Moral. Das ethische Fundament der Sozialen Marktwirtschaft [Market with Morals. The Ethical Foundation of the Social Market Economy] (Verlag Bertelsmann Stiftung, Gu“ tersloh), pp. 35-43.

Spilotis, S. S.: 2006, 'Corporate Responsibility and Historical Injustice', in J. Keane (ed.), Civil Society. Berlin Perspectives (Berghahn Books, New York), pp. 51-69.

Task Force on Corporate Social Performance: 1979, Corporate Social Reporting in the United States and Western Europe (U.S. Department of Commerce, Washington, D.C.).

Tsalikis, J. and B. Seaton: 2007, 'The International Business Ethics Index - European Union', Journal of Business Ethics 75(3), 229-238.

Ulrich, P., Y. Lunau and T. Weber: 1996, Ethikmassnahmen in der Unternehmenspraxis. Zum Stand der Wahrnehmung und Institutionalisierung von Unternehmensethik in schweizerischen und deutschen Firmen. Ergebnisse einer Befragung [Ethics in Business Practice. On the State of Perceptions and Institutionalization of Business Ethics in Swiss and German Companies. Results of a Survey] (Institut fu" r Wirtschaftsethik of the University of St. Gallen, Switzerland).

Vogel, D.: 2005, The Market for Virtue. The Potential and Limits of Corporate Social Responsibility (Brookings Institution Press, Washington, D.C.). 
Waddock, S.: 2004, 'Parallel Universes: Companies, Academics, and the Progress of Corporate Citizenship', Business and Society Review 109(1), 5-42.

Wartick, S. and D. J. Wood: 1998, International Business and Society (Blackwell Business, Malden, $\mathrm{MA})$.

Wendt, P. U.: 2000, 'Unternehmen und Jugendarbeit - als Partner in einem Boot?' [Corporations and Youth Work - As Partners in the Same Boat?], in P. U.

Wendtm, M. Perik, W. Schmidt and U. Neumann (eds.), Managementkonzepte in der modernen Jugendarbeit (Schüren, Marburg), pp. 137-141.

Wood, D.: 1991, 'Corporate Social Performance Revisited: Toward a Paradigm for Social Issues in Management', Academy of Management Review 16(4), 691-718. Zadek, S.: 2004, 'On Civil Governance', Development 47(3), 20-28.

\title{
Notes
}

\begin{abstract}
"Matten and Moon (2008) distinguish between "implicit" and "explicit" CSR and suggest that the high degree of social and environmental legislation in the coordinated market economies has led to an implicit approach to CSR as opposed to the explicit one prevalent in the liberal market economies. At first glance, this distinction appears attractive, but a closer look reveals that it risks oversimplifying and thereby yet again masking important features of reality. The relations between business and society have been shaped in coordinated market economies like France and Germany in particular by mandatory legislation and collective bargaining/ social dialogue. These forms of regulation have indeed left little space and need for voluntary CSR initiatives. However, this does not mean that stakeholders' expectations and companies' practices in this field can be characterized as purely implicit. On the contrary, the institutionalization of workers' representation in the governance organs of major German companies has required management to engage explicitly in dialogue with stakeholders' about their expectations. Probably, the legal context even contributed to make the corporate social and environmental performance more explicit and more systematic than in the United States and the United Kingdom. There is an inherent danger in reducing the characterization of CSR to the dichotomous categories voluntary/mandatory and implicit/explicit. They detract attention from what actually matters most, namely the effectiveness and the performance of the policies and practices (Wood, 1991). Why should a company's contribution to society in one country be considered less "responsible" than in another only because the legislator has made it compulsory?
\end{abstract}

ii The concurrent re-emergence of interest in civic engagement in the community in Germany in the late 1990s (Enquêtekommission, 2002) probably helped fuel the corporate citizenship approach. This may also explain why the understanding and practice of Corporate Citizenship in Germany currently corresponds more to what Doane (2005) criticizes as a self-serving managerial ideology rather than as an umbrella concept encompassing all kinds of CSR activities (e.g., Waddock, 2004).

iii More than 30 German corporations from diverse industries have signed the Global Compact, including Allianz AG, BASF AG, DaimlerChrysler AG, Deutsche Bank AG, Deutsche Lufthansa AG, Faber Castell AG, Infineon AG, and Otto $\mathrm{GmbH} \&$ Co KG.

iv Exceptions are the Institut für ökologische Wirtschaftsforschung (IÖW), established in 1985 to explore the connection between ecological sustainability and economics and expanded its focus to CSR, and the Social Science Research Center Berlin (WZB), which started addressing issues relating to the roles and responsibilities of business in society in 1975 . 


\footnotetext{
${ }^{v}$ Similar trends in other European countries use different terms: in the UK this concept is referred to as "joined-up government," and the European Union refers to "good governance."

vi The active involvement of EWC grows out of the important role of national works councils in Germany, whereas other countries tend to negotiate only with trade unions.
} 